\title{
ACCESSORY AURICLES - REPORT OF TWO CASES
}

\author{
Dejan D. Vulovic ${ }^{1,4}$, Marko B. Spasic ${ }^{2,4}$, Slobodan S. Milisavljevic ${ }^{2,4}$ and Milos A. Vucetic ${ }^{3}$ \\ ${ }^{1}$ Center for Plastic Surgery, Clinical Center Kragujevac, Kragujevac, Serbia \\ ${ }^{2}$ Clinic for General and Thoracic Surgery, Clinical Center Kragujevac, Kragujevac, Serbia \\ ${ }^{3}$ Department of Hand Surgery, Plastic and Reconstructive Surgery. Institute for Orthopedic Surgery "Banjica”, Belgrade, Serbia \\ ${ }^{4}$ University of Kragujevac, Faculty of Medical Sciences, Kragujevac, Serbia
}

\author{
AKCESORNE AURIIULE - PRIKAZ DVA SLUČAJA \\ Dejan D. Vulović ${ }^{1,4}$, Marko B. Spasić ${ }^{2,4}$, Slobodan S. Milisavljević 2,4 and Miloš A. Vučetić ${ }^{3}$ \\ ${ }^{1}$ Centar za plastičnu hirurgiju, Klinički centar Kragujevac, Kragujevac, Srbija \\ ${ }^{2}$ Klinika za opštu i grudnu hirurgiju, Klinički centar Kragujevac, Kragujevac, Srbija \\ ${ }^{3}$ Odsek za hirurgiju šake, plastičnu i rekonstruktivnu hirurgiju. Institut za ortopedsko- hirurške bolesti "Banjica“, Beograd \\ ${ }^{4}$ Univerzitet u Kragujevcu, Fakultet medicinskih nauka, Kragujevac, Srbija
}

\section{ABSTRACT}

Accessory auricle is a rare anomaly with an estimated incidence rate of 0.2-0.5\%. The most common form of this malformation is the accessory tragus. It may be a sign of other syndromes, such as oculo-auriculo-vertebral dysplasia (Goldenhar's syndrome). In this paper, we describe two cases of accessory auricle with a focus on diagnosis and surgical treatment.

Keywords: accessory auricles, surgical treatment, congenital syndromes

\section{SAŽETAK}

Akcesorne aurikule su retka anomalija sa incidencom 0,2-0,5\%. Najčešći oblik ove malformacije je akcesorni tragus. Može da bude u sklopu pojedinih sindroma, kao što je okuloaurikulovertebralna displazija (Glodenharov sindrom). U ovom radu opisujemo dva bolesnika sa akcesornim aurikulama uz posebnu pažnju na dijagnostiku i hirurški tretman.

Ključne reči: akcesorne aurikule, hirurški tretman konmgenitalni sindromi

\section{INTRODUCTION}

Accessory auricle (polyotia) is one of the most common congenital anomalies of the ear. This anomaly is the result of a disruption in the development of branchial arc I or II and is thought to be an autosomal dominantly inherited disorder, with an incidence rate of $0.2-0.5 \%$. Accessory auricles usually present unilaterally and are more frequent in male patients. It can be solitary or multiple with different morphology and localization (1-3). The most frequent localization is on the face in front of the tragus. It could be an isolated malformation or be associated with other anomalies, such as cleft lip or palate, hypoplasia of the lower jaw, and eye and spine abnormalities. It could be a component of another syndrome and is best known as Goldenhar's syndrome (oculo-auriculo-vertebral dysplasia). The most common and mildest form of this malformation is accessory tragus. Sometimes, larger accessory auricles may be found on the face or neck as a cartilaginous skeleton covered with skin. This anomaly is rarely seen in other regions, such as the middle ear and the pharynx. The definitive diagnosis of an accessory auricle is achieved by post-excisional histological analysis.

\section{CASE REPORT 1}

A 23-year-old male patient was admitted to the Clinical Center Kragujevac in Serbia for surgical treatment of multiple skin tumours that were localized between the tragus and the corner of the mouth (Figure 1). The largest tumour had a fistulous channel and secreted cerumen. There were no

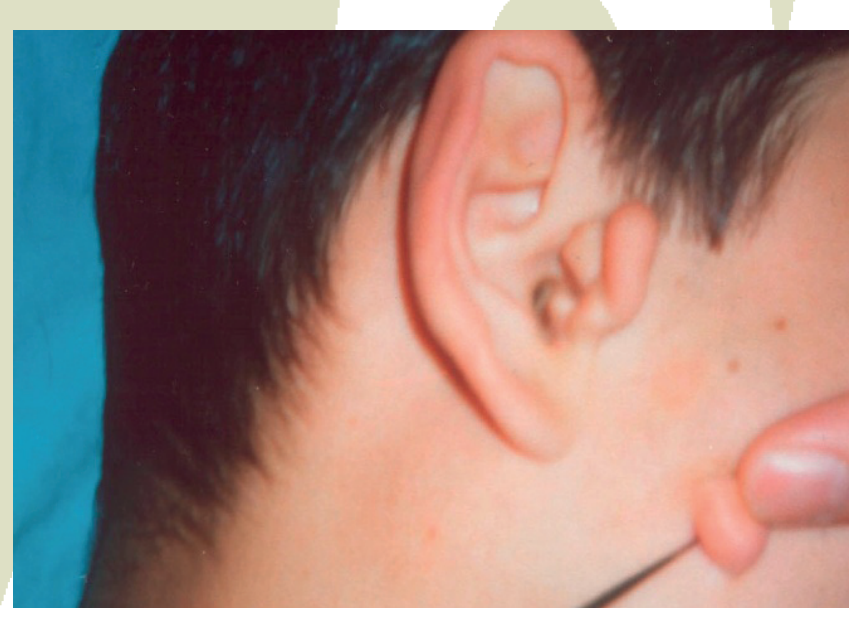

Figure 1 Local findings in case 1 (sound probe in the canal) 


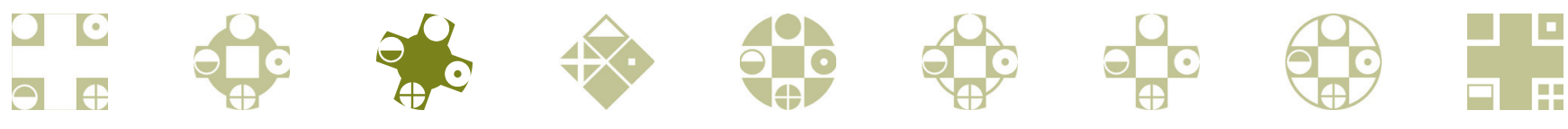

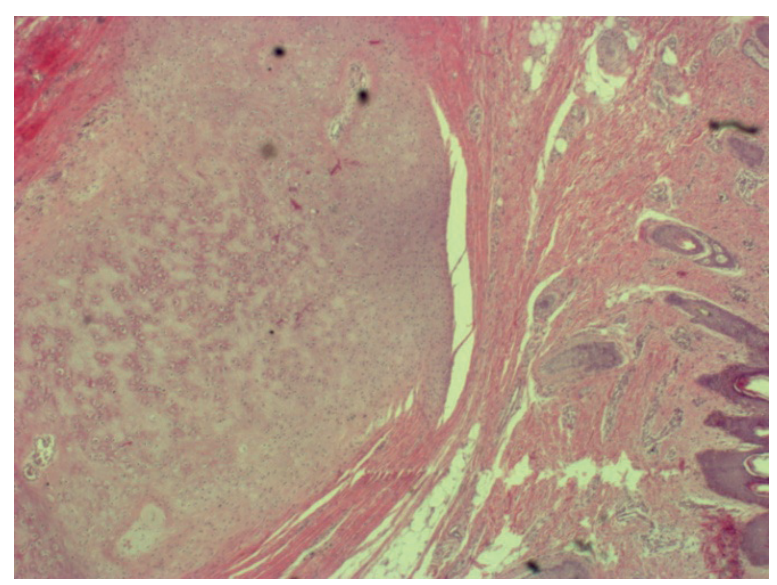

Figure 2 Histopathology (HE, 40X) of the excised accessory auricle of case 1

openings of the channels into the mouth. Ophthalmologists and otorhinolaryngologists were consulted, and the patient had no other anomalies. All of the tumours were completely removed together with the fistulous channel to the level of the facial muscles. Histopathology confirmed that this was an inherited anomaly (Figure 2). He was discharged from the hospital on the $3^{\text {rd }}$ postoperative day with no complications, and at the last follow-up examination three months after surgery, there were no signs of recurrence.

\section{CASE REPORT 2}

A one-year-old male patient underwent surgery at the Clinical Center Kragujevac in Serbia because of a growth on the left side of the neck that was medial to the anterior edge of the sternocleidomastoid muscle (Figure 3). Ophthalmologists and otorhinolaryngologists were consulted, and the patient had no other anomalies. During surgery, the fistulous channel, which extended to the common carotid artery bifurcation, was completely removed. Histopathological analysis confirmed that the growth was an accessory auricle. The postoperative period was uncomplicated, and the patient was discharged from the clinic on the $3^{\text {rd }}$ postoperative day. There was no recurrence during the three-month observation period.

\section{DISCUSSION}

Congenital anomalies of the ear are numerous but relatively rare. Their aetiology is not known. Data in the literature indicate that the incidence of these malformations is 1:6000 and is most prevalent among the Japanese population and the Navajo Indians (4). It is thought that ear malformations occur due to improper fusion of the six auricular hillocks during auricle development. One of the most common congenital anomalies of the ear is the accessory auricle. In most cases, it is a mild malformation that manifests as a supplementary tragus in front of the normal

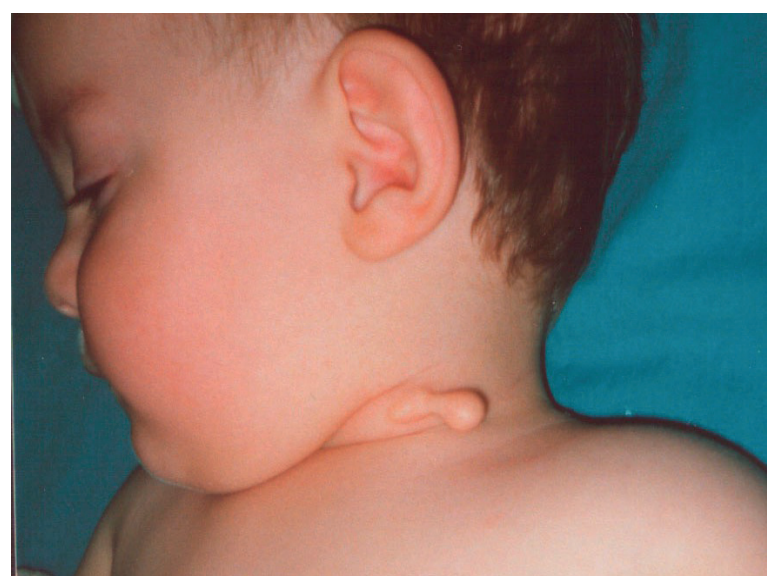

Figure 3 Local findings in case 2

tragus or at the ascending crus of the antihelix. The more severe anomalies are less common, and those with a morphologically formed auricle are referred to as polyotia (59). This is a very rare form of malformation and is defined as an accessory auricle that, by its size and morphology, resembles a normal auricle. Accessory auricles are more common in male patients and are unilateral in $90 \%$ of cases (10). This anomaly most frequently occurs on the face, but it can be found on other locations such as the lateral side of the neck $(11,12)$, suprasternal region (13), middle ear (14), Eustachian tube (15), nasopharynx $(16,17,18)$, oropharynx (19) and nasal vestibule (20).

Many genetic studies of accessory auricle have indicated that it is an autosomal, dominantly inherited disorder, although there have also been reports of it being acquired from X-linked recessive and autosomal recessive inheritance. One study analysed gene maps of 11 families for the autosomal dominant accessory auricular anomaly (ADAA) and showed that it was an autosomal dominant abnormality with complete penetration, and the isolated gene locus was 14q11.2-q12 (21). According to numerous studies, accessory auricle may be associated with other congenital anomalies. Goldenhar's syndrome is the most common form and is also known as oculo-auriculo-vertebral syndrome (OAV) (22-24). This is a rare syndrome with incomplete ear, nose, soft palate, lip, and lower jaw development, and often occurs with spinal scoliosis and lordosis. Sometimes, there are anomalies of internal organs such as the heart, lungs and kidneys. The incidence of this syndrome in the UK is $1 / 3,500$ to $1 / 26,000$. These anomalies are unilateral in $90 \%$ of cases. They are frequently accompanied by limbal dermoid of the eye, accessory tragus, and strabismus. The following syndromes are much rarer: WolfHirschhorn syndrome (WHS) $(25,26)$, also known as chromosome 4p deletion syndrome; and Pitt-Rogers-Danks syndrome (PRDS) or Pitt's syndrome. The main features are microcephaly, micrognathia, hypertelorism, accessory auricle, short philtrum, prominent glabella, psychophysical retardation, muscular hypotonia, and abnormalities of the heart. Less common features are hypospadias, iris 
coloboma, renal abnormalities, and IgA deficiency. Multiple accessory tragus and aplasia cutis congenita are part of the rare Preston Delleman's syndrome (oculocerebrocutaneous syndrome) (27). Townes-Brocks syndrome (TBS) is extremely rare and occurs in only 200 people worldwide. It is the result of mutations in the SALL1 gene and is autosomal dominantly inherited. It is characterized by accessory tragus, inner ear anomalies, and malformations of the anorectal region, heart, kidneys, hands and feet.

Accessory auricle is diagnosed by clinical examination and histopathologic analysis. It is usually treated surgically and usually involves a radical excision into the periphery and below the growth $(2,5)$. The operative duration is dependent on the severity of the anomaly and the presence of associated anomalies. Occasionally, preoperative fistulography is required. In addition to traditional excision, other surgical methods have been described such as the application of special clips (28), which may be useful for milder forms of the anomaly and for those without a fistula.

The diagnosis of accessory auricle is usually based on clinical examination and sometimes requires fistulography; a consultation to rule out the possibility of a skin tumour is also warranted. Therefore, definitive diagnoses are possible only after histopathological analysis of the completely excised skin lesion. It is important to exclude the associated anomalies, especially in the middle and inner ear as well as the eye. Accessory tragus is a feature of Goldenhar's syndrome, and therefore, otorhinolaryngological and ophthalmological examination is recommended. Occasionally, there is a need for paediatric or genetic consultation. Treatment of this anomaly is surgery (30). Since the rudimentary canal may spread to the deeper facial and neck neurovascular structures, a plastic surgeon and/or otorhinolaryngologist should be consulted.

\section{DECLARATION OF CONFLICTS OF INTEREST}

The authors declare that they have no conflicts of interest.

\section{REFERENCES}

1. Akyol MU. Accessory auricle. Otolaryngol Head Neck Surg 2000; 122: 155.

2. Jones S, Alvi R, Burton D. Accessory auricles: unusual sites and the preferred treatment option. Arch Pediatr Adolesc Med 1996; 150: 769-70.

3. Brownstein MH, Wanger N, Helwig EB. Accessory tragi. Arch Dermatol 1971; 104: 625-31.

4. Beder LB, Kemaloğlu YK, Maral I, Serdaroğlu A, Bumin MA. A study on the prevalence of accessory auricle anomaly in Turkey. Int J Pediatr Otorhinolaryngol 2002; 63: 25-7.

5. Pan B, Qie S, Zhao Y, Tang X, Lin L, Yang Q, Zhuang H, Jiang H. Surgical management of polyotia. J Plast Reconstr Aesthet Surg 2010; 63: 1283-8.
6. Demirseren ME, Afandiyev K, Durgun M, Seven E, Belenli O. An unusual auricular malformation accompanied by accessory tragus: macrotragus. Eur Arch Otorhinolaryngol 2008; 26 5: 639-41.

7. Sauter R, Villavicencio E, Schwager K. Doubling of the pinna, a rare branchial arch developmental disorder. Laryngorhinootologie 2006; 85: 657-60.

8. Ku PK, Tong MC, Yue V. Polyotia- a rare external ear anomaly. Int J Pediatr Otorhinolaryngol 1998; 46: 117-20.

9. Katsuragi M, Kojima T, Shimbashi T. Polyotia. A case report. Handchir Mikrochir Plast Chir 1992; 24:187-90.

10. Cosman BC. Bilateral accessory tragus. Cutis 1993;51:199-200.

11. Konaş E, Canter HI, Mavili ME. Cervical accessory auricula. J Craniofac Surg 2006; 17: 713-5.

12. Punyamurthy M. Accessory auricles in the neck. J Laryngol Otol 1972; 86: 173-4.

13. Kim SW, Moon SE, Kim JA. Bilateral accessory tragi on the suprasternal region. J Dermatol 1997; 24: 543-5.

14. Chintalapati K, Gunasekaran S, Frewer J. Accessory tragus in the middle ear: A rare congenital anomaly. Int J Pediatr Otorhinolaryngol 2010; 74: 1338-9.

15. Münker G. Accessory auricle in the eustachian tube. Z Laryngol Rhinol Otol 1972; 51: 175-8.

16. Jiang SH, Zhang QQ, Zhang $\mathrm{H}$, et al. Accessory auricle in the nasopharynx in a case. Zhonghua Er Bi Yan Hou Tou Jing Wai Ke Za Zhi 2007; 42:706.

17. Heffner DK, Thompson LD, Schall DG, Anderson V. Pharyngeal dermoids ("hairy polyps") as accessory auricles. Ann Otol Rhinol Laryngol 1996; 105: 819-24.

18. Schuring AG. Accessory auricle in the nasopharynx. Laryngoscope 1964; 74: 111-4.

19. Schendzielorz P, Brusis T, Arnold G. Accessory external ear in the oropharynx. Laryngol Rhinol Otol (Stuttg) 1985; 64:586-7.

20. Shin MS, Choi YJ, Lee JY, Lee SH, Ahn JY, Park MY, Park HJ. A case of accessory tragus on the nasal vestibule. Ann Dermatol 2010; 22: 61-2.

21. Yang Y, Guo J, Liu Z, Tang S, Li N, Yang M, et al. A locus for autosomal dominant accessory auricular anomaly maps to 14q11.2-q12. Hum Genet 2006; 120: 144-7.

22. M. Goldenhar. Associations malformatives de l'oeil et de l'oreille, en particulier le syndrome dermoïde epibulbaire-appendices auriculaires-fistula auris congenita et ses relations avec la dysostose mandibulo-faciale. Journal de génétique humaine 1952; 1: 243-82.

23. Khadir K, Habibeddine S, Bouanane N, Lakhdar $\mathrm{H}$. Multiple accessory tragi and Goldenhar's syndrome. Arch Pediatr 2006; 13: 1557-8.

24. Mehta B, Nayak C, Savant S, Amladi S. Goldenhar syndrome with unusual features. Indian J Dermatol Venereol Leprol 2008; 74: 254-6.

25. Wolf U, Reinwein H, Porsch R, Schröter R, Baitsch H. (1965). Deficiency on the short arms of a chromosome No. 4. Humangenetik 1965; 1: 397-413. 
26. Hirschhorn K, Cooper HL, Firschein IL. Deletion of short arms of chromosome 4-5 in a child with defects of midline fusion. Humangenetik 1965; 1 : 479-82.

27. Agim NG, Hunt CM, Williams VL, Metry DW. Multiple congenital facial papules-quiz case. Multiple accessory tragi and aplasia cutis congenita in association with Delleman (oculocerebrocutaneous) syndrome. Arch Dermatol 2011; 147: 345-50.
28. Moon IY, Oh KS. Surgical correction of an accessory auricle, polyotia. Arch Plast Surg 2014;4: 427-9.

29. Skillman J, Cerovac S, Fleming A, Moss AL. Titanium clips: a simple technique for the excision of accessory tragi and digits. Br J Plast Surg 2002; 55: 589.

30. Altuntaş EE1, Nur N, Cerrah YS, Müderris S. A study of the prevalence of developmental anomalies of the external ear among preschool children in Sivas, Turkey. Turk J Pediatr 2011;53(5):528-31. 